\title{
Multidimensional niche differentiation might buffer invasion impacts: the case of oligohaline corophiids (Crustacea: Amphipoda) in the Baltic Sea
}

\author{
Péter Borza 10 - Kęstutis Arbačiauskas • Michael L. Zettler
}

Received: 21 April 2020/Accepted: 5 February 2021/Published online: 18 February 2021

(C) The Author(s) 2021

\begin{abstract}
Multidimensional niche differentiation might increase the stability of coexistence by reducing overall niche overlap which might have implications on the dynamics of biological invasions. The oligohaline Baltic Seais inhabited by three native and one invasive corophiid amphipod species. These filter feeding crustaceans differ in their substrate preferences and salinity optima which could potentially allow their robust coexistence. However, recent theory predicts that competing species must diverge across all non-substitutable resources (e.g., food and space). We have measured the filter mesh size in the four species (i.e., the distance between bristles on the filtering setae), revealing considerable differences among the three natives (Apocorophium lacustre, Corophium multisetosum and C. volutator), whereas the invasive Chelicorophium curvispinum showed strong overlap with A. lacustre. Theory suggests that the four species cannot coexist robustly due to their overlap in food
\end{abstract}

P. Borza $(\bowtie)$

Danube Research Institute, Centre for Ecological

Research, Karolina út 29, 1113 Budapest, Hungary

e-mail: borza.peter@ecolres.hu

K. Arbačiauskas

Nature Research Centre, Akademijos Str. 2,

08412 Vilnius, Lithuania

M. L. Zettler

Biological Oceanography, Leibniz-Institute for Baltic Sea

Research, Seestrasse 15, 18119 Rostock, Germany particle size irrespective of differences in their salinity optima and substrate preferences which is in accordance with observations of local extinctions of $A$. lacustre. Nevertheless, the stability ensuing from the multidimensional niche differentiation might delay competitive exclusion; i.e., the spatial separation by salinity and substrate types might decrease the intensity of competition for food. Our data for co-occurring populations indicate that $A$. lacustre might be able to decrease its filter mesh size overlap with $C$. curvispinum by character displacement and its broader salinity tolerance also might help the native species to persist in the region. However, the niche shift of the species might increase its overlap with $C$. multisetosum.

Keywords Coexistence - Filter mesh size - Salinity · Species packing $\cdot$ Suspension feeding

\section{Introduction}

Understanding the mechanisms allowing the coexistence of species with overlapping resource requirements is one of the main goals of community ecology. Most theoretical works have focused on identifying the minimal conditions of robust coexistence, reaching the conclusion that the number of species cannot exceed the number of factors regulating their population sizes (Chase and Leibold 2003). However, in 
natural situations the number of potential regulating factors is often higher than the number of coexisting species. Recently, Ashby et al. (2017) demonstrated that increasing the number of niche axes does not necessarily increase diversity since disruptive selection drives species to diverge across all non-substitutable regulating factors simultaneously. While differentiation by multiple non-substitutable resources (e.g., food and space) might not allow more species to coexist, it still has important implications on the stability of their coexistence by reducing overall niche overlap.

The significance of the phenomenon might especially be tangible in the dynamics of biological invasions (Ashby et al. 2017). Reduced niche overlap through multidimensional differentiation might on one hand promote the establishment and initial population growth of invaders. On the other hand, it also might delay or even prevent the competitive exclusion of native species in the later stages of the invasion process. While assessing the effects quantitatively would require further theoretical developments, it is useful to identify systems where the phenomenon might be relevant. In this paper, we present such a case in benthic filter feeding crustaceans.

The set of variables by which competing species can diverge (i.e., 'niche space' as defined in Pásztor et al. 2016) is determined by the biological characteristics of the organisms. In the case of benthic suspension feeders, coexistence is usually determined by competition for space and food (Svensson and Marshall 2015), although other factors such as time (e.g., in cases involving species with dormant life stages) or predators (e.g., among species with different body sizes and/or defense mechanisms) also might play a role. Spatial niche differentiation is possible if the fitness of the species shows trade-offs along environmental gradients; e.g., depth, salinity, substrate hardness, or shear stress (Brönmark and Malmqvist 1982). Niche differentiation by food also requires the species to show trade-offs in their efficiency to utilize food particles differing in some aspects.

Suspension feeding macroinvertebrates use various mechanisms for capturing particles (Shimeta and Jumars 1991; Riisgård and Larsen 2010) which have implications on selectivity. Most mechanisms involve structures with regularly repeated openings (Riisgård and Larsen 2010); therefore, filter mesh size (FMS henceforth) is a pivotal functional trait within the group. The relationship between FMS and particle size selectivity is not straightforward in all instances; e.g., adhesive forces might allow the capture of particles considerably smaller than the mesh size. Nevertheless, FMS might allow meaningful comparisons among species with similar particle capture mechanisms even in such cases (e.g., Alstad 1987). The trait is the most informative when rigid, non-adhesive structures are used for the mechanical retention of particles ('sieving'). Although all particles larger than the FMS are captured, efficiency is highest for the ones only slightly exceeding it, allowing niche differentiation by food particle size given sufficient differences in FMS among the species.

Corophiids are small (usually less than $1 \mathrm{~cm}$-long) amphipod crustaceans inhabiting mainly marine and brackish waters worldwide, with some species occurring in freshwater, as well (Bousfield and Hoover 1997). The animals typically live in their selfconstructed tubes burrowed in soft sediments or attached to hard surfaces. They generate currents within the tube by the beating of their pleopods and filter particles using the bristled setae on their second gnathopods (Møller and Riisgård 2006). The distance between the bristles (i.e., FMS) has been demonstrated to coincide with the lower size limit of retained particles, indicating that the filtering mechanism of corophiids can be regarded as mechanical sieving (Møller and Riisgård 2006). Switching to deposit feeding has also been observed in burrowing species under low concentrations of suspended food particles, during which the animals scrape the surface of the sediment with their second antennae (Riisgård and Schotge 2007). They often reach high densities (up to $>100,000$ ind. $\mathrm{m}^{-2}$; Van den Brink et al. 1993; Gerdol and Hughes 1994), exerting considerable filtering capacity (Møller and Riisgård 2006) and providing ample food source for fish and birds (McCurdy et al. 2005; MacDonald et al. 2014).

The presence of native and invasive species makes the Baltic Sea an interesting system for studying coexistence among corophiids. The family is represented in the basin by 12 native species; however, only three of them occur in oligohaline $(<5$ PSU) waters (Zettler and Zettler 2017). Corophium multisetosum Stock, 1952 and Corophium volutator (Pallas, 1766) are burrowing species tolerating a wide range of 
salinity from near fully saline to almost fresh waters (Queiroga 1990; Zettler and Zettler 2017), whereas Apocorophium lacustre (Vanhöffen, 1911) lives on hard surfaces typically in brackish estuaries and lagoons (up to 15 PSU) but occasionally also in freshwaters (Grigorovich et al. 2008; Zettler and Zettler 2017). The Ponto-Caspian invader Chelicorophium curvispinum (G. O. Sars, 1895) appeared in the Baltic Sea in the early twentieth century where it colonized hard surfaces in fresh and slightly brackish coastal waters (0-3 PSU; Meßner and Zettler 2018). Although the salinity tolerance ranges of the species overlap, their optima are apparently different, allowing the formation of zonation patterns along stable gradients; e.g., in estuaries (Buckley et al. 2004) and in polluted rivers (Bäthe 1997).

Despite the relatively intensive research on the feeding ecology of corophiids, their FMS has received little attention so far, especially in a comparative context. The only such study to our knowledge reported significant differences among three Chelicorophium species in the Lower Danube (Borza et al. 2018a). Although differences in their substrate preferences and salinity optima could potentially allow the robust coexistence of the oligohaline corophiids in the Baltic Sea, we expected them to differentiate also by food particle size, as predicted by Ashby et al. (2017). Accordingly, we measured their FMS with the aim of revealing potential niche differentiation by food particle size among the native species, and assessing how the invasive $C$. curvispinum interferes with the natives in this regard.

\section{Materials and methods}

The Baltic Sea is a relatively shallow (average depth: $57 \mathrm{~m}$ ) fjord-like arm of the Atlantic Ocean extending from the north coast of Germany almost to the Arctic Circle in Sweden and Finland (surface area: $369,000 \mathrm{~km}^{2}$, water volume: $21,000 \mathrm{~km}^{3}$ ). Its water is brackish due to the high freshwater runoff relative to its volume and the narrow strait connecting it to the ocean. The spatially and temporally highly variable salinity of the water is one of the main environmental parameters determining the occurrence, distribution, and density of organisms there (Snoeijs-Leijonmalm et al. 2017).
Altogether 284 specimens from 11 samples were included in the analysis (Fig. 1, Table 1). The offshore samples (Sites 3 and 9) were obtained by the combination of a van Veen grab $\left(0.1 \mathrm{~m}^{2}, 3\right.$ replicates $)$ and a dredge (Kieler Kinderwagen). In-shore samples from Germany were collected using a hand core (78.5 $\mathrm{cm}^{2}, 3$ replicates), a hand net, and a scraper. The samples from Lithuania (Sites 4 and 5) were collected by hand net. All samples were fixed in formaldehyde and later stored in ethanol.

The morphological measurements were done conforming to the procedure described by Borza et al. (2018a). After the measurement of standard body length (from the tip of the rostrum to the end of the telson; using ocular micrometer), microscopic preparations were made of the filtering setae. The part of the 2nd gnathopods holding the setae was dissected, mounted on a slide, and covered in Canada balsam. The measurements were made on digital photographs taken under light microscope (DIC, $1000 \times$ magnification) using the tpsDig software (Rohlf 2015). To minimize measurement error, the distance between the centers of six bristles (spanning five gaps) near the basis of the setae was measured and the mean gap between bristles was assessed by dividing the value of the measured distance by five. This procedure was repeated 10 times per specimen, each measurement performed on different setae.

FMS data were analyzed with linear mixed-effect models in R 3.6.3 (R Core Team 2020) using the 'nlme' package (Pinheiro et al. 2020). First, the FMS data of each species were modelled separately featuring individuals as a random factor, and body length, sampling sites, and their interaction as fixed factors. The optimal models were chosen based on the AIC (Akaike Information Criterion) values considering all combinations of fixed factors (Table 2). Since these models revealed significant intraspecific variability potentially related to the presence/absence of competitors, modelling interspecific differences based on all samples would be misleading in our opinion. Two species co-occurred at some sites; however, modelling interspecific differences was not feasible due to the low numbers of specimens in the less abundant species. Our conclusions regarding niche differentiation by food particle size were based primarily on the FMS ranges of the species, which are more closely associated with the concept of niche breadth/overlap than differences in means or medians (although not 


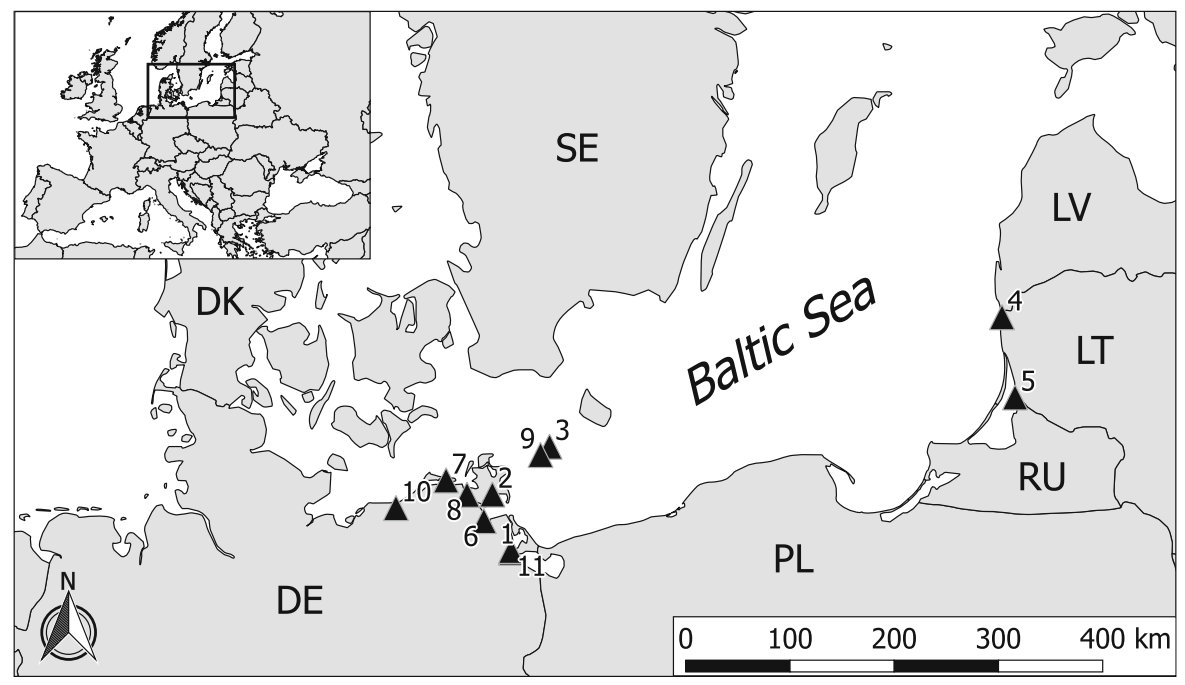

Fig. 1 Map of the sampling sites. Numbers as in Table 1. Country codes: DE: Germany, DK: Denmark, LT: Lithuania, LV: Latvia, PL: Poland, RU: Russia, SE: Sweden

directly translatable into that due to the asymmetric resource utilization functions; i.e., different efficiency of collecting particles bigger and smaller than the mesh size).

The datasets generated and analyzed during the current study are available in the figshare repository (https://doi.org/10.6084/m9.figshare.11994147).

\section{Results}

The highest FMS values were observed in C. volutator (Table 3); nevertheless, the variability of the trait was high both within and among individuals (Fig. 2a). There were significant differences among the sites, and the effect of body length was also strong (Table 4).

Chelicorophium curvispinum had the second largest FMS in our study (Fig. 2b, Table 3). The three sites were remarkably consistent; the differences among them were not significant and the slopes of the body length dependency were similar, as well (Table 4).

The FMS of A. lacustre was somewhat smaller than that of $C$. curvispinum; however, it was more variable among sites (Fig. 2c, Table 3). The effect of body length was moderate but significant (Table 4).

The FMS of $C$. multisetosum was the smallest among the studied species (Fig. 2d, Table 3). It showed low variability; the body length dependency was not significant, whereas the difference between the two sites was small but relatively consistent (Table 4).

The FMS of the two specimens of $C$. volutator found in co-occurrence with $C$. multisetosum at 'Site $2^{\prime}$ fit well within the range of the three one-species samples (Fig. 2a); accordingly, the difference between the two species was clean-cut (Fig. 3a). The single specimen of $A$. lacustre had larger FMS than $C$. multisetosum at 'Site 4' (Fig. 3b), whereas the one at 'Site $11^{\prime}$ had smaller FMS than $C$. curvispinum (Fig. 3c). Nevertheless, neither of the two individuals represented extremities compared to the three allopatric samples.

\section{Discussion}

Filter mesh sizes

To our knowledge, FMS values have previously been reported for only two of the four studied species. Our measurements on $C$. volutator are in agreement with published data, ranging from $4 \mu \mathrm{m}$ (Nielsen and Kofoed 1982) to $7.0 \pm 0.9 \mu \mathrm{m}$ (Møller and Riisgård 2006). In the case of $C$. curvispinum, the FMS of the Baltic populations was somewhat smaller and less variable than in the Lower Danube; nevertheless, the lower limit was similar (2.24 vs. $2.47 \mu \mathrm{m}$; Borza et al. 2018b). Overall, the FMS range covered by all four studied species was similar to the range of the three 
Table 1 Data of the samples included in the study

\begin{tabular}{|c|c|c|c|c|c|c|c|c|}
\hline Code & Site & Date & Coordinates & $\begin{array}{l}\text { Salinity } \\
\text { (PSU) }\end{array}$ & $\begin{array}{l}\text { Depth } \\
(\mathrm{m})\end{array}$ & Species & $\begin{array}{l}\text { Number of } \\
\text { specimens }\end{array}$ & $\begin{array}{l}\text { Body length } \\
\text { range }(\mathrm{mm})\end{array}$ \\
\hline 1 & $\begin{array}{r}\text { Anklam } \\
\text { (ferry) }\end{array}$ & 20.06 .1998 & $\begin{array}{l}53^{\circ} 51^{\prime} 00.0^{\prime \prime} \mathrm{N}, 13^{\circ} 49^{\prime} \\
59.9^{\prime \prime} \mathrm{E}\end{array}$ & 1 & $0.5-1$ & $\mathrm{CC}$ & 35 & $2.3-6.2$ \\
\hline \multirow[t]{2}{*}{2} & Lauterbach & 19.05 .2005 & $\begin{array}{l}54^{\circ} 20^{\prime} 04.2^{\prime \prime} \mathrm{N}, 13^{\circ} 29^{\prime} \\
01.2^{\prime \prime} \mathrm{E}\end{array}$ & 5.5 & 0.4 & $\mathrm{CM}$ & 18 & $3.7-5.6$ \\
\hline & & & & & & $\mathrm{CV}$ & 2 & $4.4-6.3$ \\
\hline 3 & (Open sea) & 22.04 .2012 & $\begin{array}{l}54^{\circ} 47^{\prime} 14.3^{\prime \prime} \mathrm{N}, 14^{\circ} 16^{\prime} \\
08.8^{\prime \prime} \mathrm{E}\end{array}$ & 8 & 19.3 & $\mathrm{CV}$ & 22 & $4.0-7.3$ \\
\hline \multirow[t]{2}{*}{4} & $\begin{array}{r}\text { Sventoji } \\
\text { mouth }\end{array}$ & 04.09 .2015 & $\begin{array}{l}56^{\circ} 01^{\prime} 47.0^{\prime \prime} \mathrm{N}, 21^{\circ} 04^{\prime} \\
10.0^{\prime \prime} \mathrm{E}^{\mathrm{a}}\end{array}$ & NA & $0.5-1$ & $\mathrm{CM}$ & 25 & $1.9-5.8$ \\
\hline & & & & & & $\mathrm{AL}$ & 1 & 4.3 \\
\hline 5 & $\begin{array}{l}\text { Nemunas } \\
\text { mouth }\end{array}$ & 05.09 .2015 & $\begin{array}{l}55^{\circ} 20^{\prime} 12.1^{\prime \prime} \mathrm{N}, 21^{\circ} 14^{\prime} \\
53.4^{\prime \prime} \mathrm{E}^{\mathrm{a}}\end{array}$ & NA & $0.5-1$ & $\mathrm{CC}$ & 30 & $2.0-5.5$ \\
\hline 6 & Greifswald & 05.09 .2017 & $\begin{array}{l}54^{\circ} 06^{\prime} 00.9^{\prime \prime} \mathrm{N}, 13^{\circ} 23^{\prime} \\
39.7^{\prime \prime} \mathrm{E}\end{array}$ & 6.2 & 0.5 & $\mathrm{AL}$ & 25 & $1.8-5.1$ \\
\hline 7 & Müggenburg & 29.05 .2018 & $\begin{array}{l}54^{\circ} 25^{\prime} 03.0^{\prime \prime} \mathrm{N}, 12^{\circ} 46^{\prime} \\
54.0^{\prime \prime} \mathrm{E}\end{array}$ & 5.1 & $0.5-1$ & $\mathrm{CV}$ & 20 & $5.2-7.5$ \\
\hline 8 & Dänholm & 01.06 .2018 & $\begin{array}{l}54^{\circ} 18^{\prime} 43.2^{\prime \prime} \mathrm{N}, 13^{\circ} 06^{\prime} \\
39.6^{\prime \prime} \mathrm{E}\end{array}$ & 6.2 & $0.5-1$ & $\mathrm{AL}$ & 30 & $1.9-5.7$ \\
\hline 9 & (open sea) & 16.06 .2018 & $\begin{array}{l}54^{\circ} 42^{\prime} 32.6^{\prime \prime} \mathrm{N}, 14^{\circ} 08^{\prime} \\
43.0^{\prime \prime} \mathrm{E}\end{array}$ & 7.8 & 12 & $\mathrm{CV}$ & 24 & $4.6-7.6$ \\
\hline 10 & Schmarl & 24.09 .2018 & $\begin{array}{l}54^{\circ} 08^{\prime} 06.6^{\prime \prime} \mathrm{N}, 12^{\circ} 05^{\prime} \\
20.2^{\prime \prime} \mathrm{E}\end{array}$ & 12 & $0.5-1$ & $\mathrm{AL}$ & 24 & $1.5-4.5$ \\
\hline \multirow[t]{2}{*}{11} & Zecherin & 25.09 .2018 & $\begin{array}{l}53^{\circ} 51^{\prime} 54.0^{\prime \prime} \mathrm{N}, 13^{\circ} 49^{\prime} \\
51.6^{\prime \prime} \mathrm{E}\end{array}$ & 1.2 & $0.5-1$ & $\mathrm{CC}$ & 27 & $1.9-4.5$ \\
\hline & & & & & & $\mathrm{AL}$ & 1 & 2.7 \\
\hline
\end{tabular}

AL A. lacustre, CC C. curvispinum, CM C. multisetosum, CV C. volutator

${ }^{\mathrm{a}}$ Approximate coordinates

Table 2 The $A I C$ values of the models with different fixed effects (*: with interaction, +: without interaction)

\begin{tabular}{lccccc}
\hline Species & Length $*$ site & Length + site & Length & Site & Intercept only \\
\hline C. volutator & 1380.13 & 1377.42 & 1406.44 & 1406.92 & 1433.63 \\
C. curvispinum & 178.83 & 170.32 & 162.43 & 235.03 & 240.15 \\
A. lacustre & 437.25 & 435.44 & 489.69 & 445.08 & 495.33 \\
C. multisetosum & -186.32 & -190.59 & -190.95 & -196.07 & -192.25 \\
\hline
\end{tabular}

The lowest values (indicating the optimal model) are italics

Table 3 The FMS ranges of the species in $\mu \mathrm{m}$

\begin{tabular}{lll}
\hline Species & Range (by measurements) & Range (individual means) \\
\hline C. volutator & $3.05-9.6$ & $3.75-8.12$ \\
C. curvispinum & $2.24-5.23$ & $2.50-4.79$ \\
A. lacustre & $1.40-5.82$ & $1.57-4.65$ \\
C. multisetosum & $1.45-2.83$ & $1.56-2.44$ \\
\hline
\end{tabular}




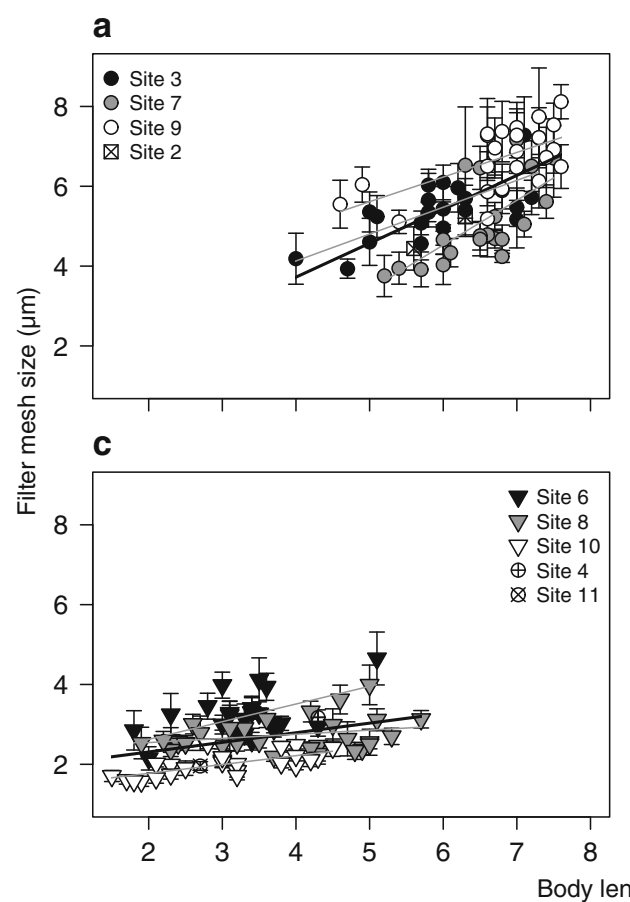

Fig. 2 The FMS (individual means \pm SD) of the four species based on all samples; a $C$. volutator, b C. curvispinum, c $A$. lacustre, $\mathbf{d}$ C. multisetosum. Thick black lines correspond to the b

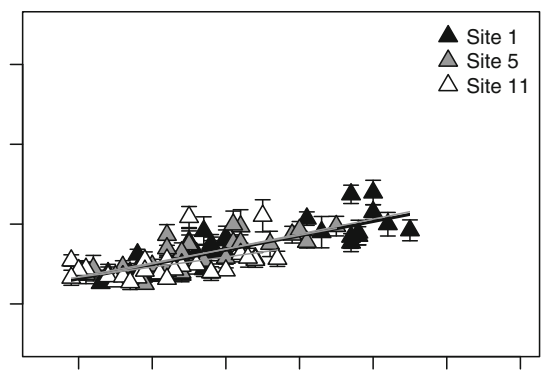

d

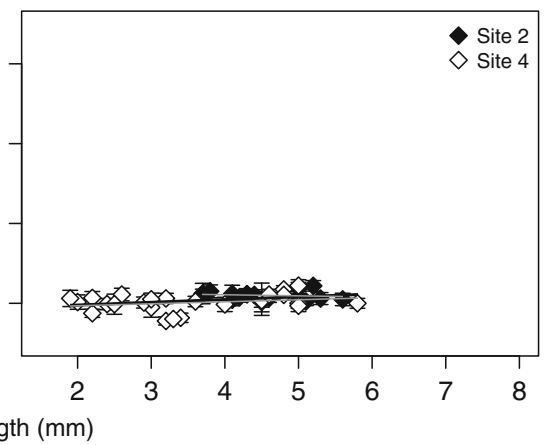

slope of overall body-length dependency; thin grey lines indicate the slope of body-length dependency by samples

Table 4 Parameter estimations of the optimal models based on the $A I C$ values (as in Table 2)

\begin{tabular}{llcrrrr}
\hline Species & Parameter & Estimated value & $S E$ & $d f$ & $t$ & $P$ \\
\hline C. volutator (without Site_2) & (Intercept) & 1.03 & 0.68 & 594 & 1.51 & 0.1308 \\
& Length & 0.74 & 0.11 & 62 & 6.67 & $<0.0001$ \\
& Site_7 & -0.76 & 0.22 & 62 & -3.48 & 0.0009 \\
& Site_9 & 0.66 & 0.22 & 62 & 3.02 & 0.0037 \\
C. curvispinum & (Intercept) & 1.91 & 0.12 & 828 & 16.39 & $<0.0001$ \\
& Length & 0.36 & 0.03 & 90 & 11.78 & $<0.0001$ \\
A. lacustre (without Site_4 and 11) & (Intercept) & 1.97 & 0.20 & 711 & 9.96 & $<0.0001$ \\
& Length & 0.20 & 0.05 & 75 & 4.17 & 0.0001 \\
& Site_6 & 0.54 & 0.11 & 75 & 4.83 & $<0.0001$ \\
C. multisetosum & Site_10 & -0.58 & 0.12 & 75 & -5.00 & $<0.0001$ \\
& (Intercept) & 2.20 & 0.04 & 378 & 51.26 & $<0.0001$ \\
& Site_4 & -0.18 & 0.06 & 40 & -3.28
\end{tabular}

Ponto-Caspian corophiids in the Lower Danube (1.40-9.60 vs. 1.03-7.17; Borza et al. 2018b). We presume that there might be morphological or energetic constraints limiting the range of filter mesh size within the group, which-coupled with the ecological constraint of limiting similarity-might allow the coexistence of maximum three species by niche differentiation along the food particle size spectrum.

The body length-dependence of FMS was also observed in the Lower Danube (Borza et al. 2018a), 


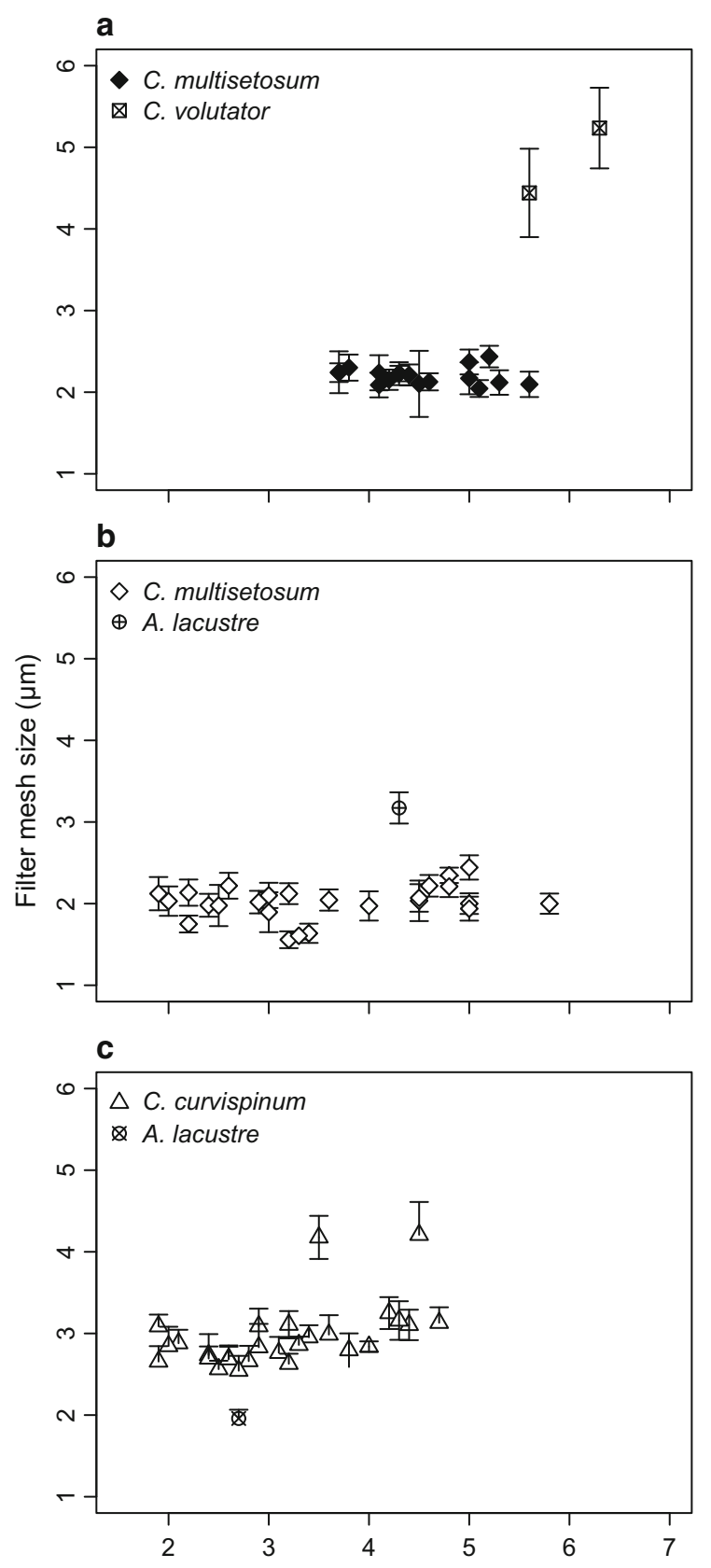

Fig. 3 FMS (individual means \pm SD) in the samples where two species co-occurred; a Site 2, b Site 4, c Site 11. Symbols correspond to Fig. 2

where the effect was similar for all three Chelicorophium species (except for large-sized C. robustum). In contrast, the slope varied considerably among the species included in this study. The effect was the strongest in C. volutator; however, the unfortunate absence of small specimens in our samples somewhat increases the uncertainty of the estimation. The slope in C. curvispinum was remarkably similar to that in the population in the Lower Danube (0.36 vs. 0.40; Borza et al. 2018b) despite the high among- and withinindividual variation of FMS in the latter. The apparent absence of the body length dependency in $C$. multisetosum makes it the only exception among the corophiids studied so far in this regard. Since the samples included in the study were collected at different times of the year which did not have a significant effect on the body-length dependence of FMS (i.e., the body length-site interactions were not significant in any of the species), our results indicate that the size-related differences in the trait might indeed be related to ontogenetic changes (i.e. they do not reflect differences among cohorts-a possibility which could not be excluded based on the one-time sampling in Borza et al. 2018a). The relevance of the phenomenon might lie in decreasing the intensity of intraspecific competition (Ebenman 1988). The range of divergence might be limited by the size-distribution of food particles and the presence of competitors.

The present study is the first to report intraspecific differences in the FMS of corophiids among samples. Although sampling time/season was not explicitly included in the analysis, its role can most likely be excluded, since both in $C$. volutator and A. lacustre the two samples collected the closest seasonally were the most dissimilar. Therefore, the differences in FMS among samples are probably determined by spatially variable environmental factors. All three native species showed such variability, and although it was not observed within the Baltic population of $C$. curvispinum, the comparison with the Lower Danube (Borza et al. 2018b) reflects flexibility even in this species. We presume that the phenomenon might be universal among corophiids; however, more research is needed to reveal the mechanism and the factors determining this variation. Our results on A. lacustre (Fig. 3b, c) suggest that intraspecific variation might be related to the local abundance of competitors, reflecting character displacement. It seems plausible that the species are capable of adapting their morphology to food availability by phenotypic plasticity-similarly to Daphnia spp. (Lampert 1994; Bednarska 2006) — and/or by microevolutionary processes induced by directional selection. 
Multidimensional niche differentiation

The three native oligohaline species in the Baltic Sea showed differences in FMS similar to the three PontoCaspian species in the Lower Danube (Borza et al. 2018a) indicating niche differentiation by food particle size. Combined with differences in their substrate preferences and salinity optima, the coexistence of the three species can be interpreted in a multidimensional niche space. Since food and space are non-substitutable resources, the species are expected to diverge simultaneously along them, so the system represents a sparsely packed but saturated niche space where the number of coexisting species is limited by one axis (Ashby et al. 2017). Nevertheless, differentiation in multiple dimensions might increase the robustness of the coexistence which can be relevant especially in such a variable habitat as the Baltic Sea. Since salinity in estuarine systems can change dynamically in time and substrates types occur usually mixed, the possibility of spatial separation might often be limited. Accordingly, the food source might often be shared among the species due to the spatial proximity of individuals and the mixing effect of currents, making differentiation by food particle size essential. Remarkably, the two native species most similar in habitat use-C. multisetosum and C. volutator-showed the most pronounced differentiation in FMS, and the one utilizing the middle of the particle size spectrum $(A$. lacustre) inhabits different substrates. Although it has been proposed that associations between different components of a species' niche might be arbitrary (Ashby et al. 2017), this pattern suggests that trait combinations might evolve in a way to further decrease niche overlap when continuous niche axes and more than two species are involved.

The appearance of $C$. curvispinum must have represented a major disturbance in this fine-tuned system. Theory predicts that the four species cannot coexist robustly due to their overlap in food particle size irrespective of differences in their salinity optima and substrate preferences (Ashby et al. 2017); nevertheless, the stability ensuing from the multidimensional niche differentiation might delay competitive exclusion. The invader shows the strongest overlap with A. lacustre regarding their FMS ranges as well as their substrate preferences which might explain the disappearance of this native species in certain areas (Noordhuis et al. 2009). Although the plasticity of $A$. lacustre might decrease the intensity of competition through character displacement, the shift towards smaller FMS might result in a stronger overlap with $C$. multisetosum, so the effect of the invader might be transmitted to this species as well. Its broader salinity tolerance also helps A. lacustre to persist in the region; however, the tolerance of the invader might shift in time (Meßner and Zettler 2018), further increasing the pressure on the native species.

In summary, our case study revealed an interesting system worthy of further investigation from both theoretical and applied perspectives. Although there might be additional complexities not included in the present study, we expect them to complement and not to override our conclusions. Predation for instance might represent an important limiting factor; however, since the species are morphologically very similar, predators cannot be expected to discriminate among them. Their effect might implicitly be included in the substrate preference of the species, assuming different predators to forage on soft and hard substrates. The ability to switch to deposit feeding might further increase the stability of the system by allowing the species to avoid competition under low concentrations of suspended food particles; however, this way they could enter competition with other deposit feeding organisms.

Acknowledgements The authors wish to thank Éva Ács, Csilla Balogh, Mónika Duleba, Angéla Földi, Zoltán Sefőző, and Zsuzsanna Trábert for their technical support. Project No. 132605 and 2.3.2-15-2016-00019 have been implemented with the support provided from the National Research, Development and Innovation Fund of Hungary, financed under the FK_19 and GINOP funding schemes, respectively.

Author contributions MLZ and KA carried out the field work, identified the species, reviewed and edited the manuscript. PB made the morphological measurements, analyzed the data, and wrote the manuscript.

Funding Open access funding provided by ELKH Centre for Ecological Research.

Availability of data and materials The datasets generated and analyzed during the current study are available in the figshare repository (https://doi.org/10.6084/m9.figshare. 11994147). Freely accessible after publication.

Code availability $\mathrm{R}$ codes are available from the corresponding author on reasonable request. 


\section{Compliance with ethical standards}

Conflict of interest The authors declare that they have no conflict of interest.

Ethical approval All applicable institutional and/or national guidelines for the care and use of animals were followed.

Consent to participate Not applicable.

Consent for publication On acceptance, the authors agree to transfer the copyrights to the Publisher.

Open Access This article is licensed under a Creative Commons Attribution 4.0 International License, which permits use, sharing, adaptation, distribution and reproduction in any medium or format, as long as you give appropriate credit to the original author(s) and the source, provide a link to the Creative Commons licence, and indicate if changes were made. The images or other third party material in this article are included in the article's Creative Commons licence, unless indicated otherwise in a credit line to the material. If material is not included in the article's Creative Commons licence and your intended use is not permitted by statutory regulation or exceeds the permitted use, you will need to obtain permission directly from the copyright holder. To view a copy of this licence, visit http://creativecommons.org/licenses/by/4.0/.

\section{References}

Alstad DN (1987) Particle size, resource concentration, and the distribution of net-spinning caddisflies. Oecologia 71:525-531. https://doi.org/10.1007/BF00379291

Ashby B, Watkins E, Lourenço J, Gupta S, Foster KR (2017) Competing species leave many potential niches unfilled. Nat Ecol Evol 1:1495-1501. https://doi.org/10.1038/ s41559-017-0295-3

Bäthe J (1997) Decreasing salinity in Werra and Weser (Germany): reactions of the phytoplankton and the macrozoobenthos. Limnologica 27:111-119

Bednarska A (2006) Adaptive changes in morphology of Daphnia filter appendages in response to food stress. Pol J Ecol 54:663-668

Borza P, Huber T, Leitner P, Remund N, Graf W (2018a) Niche differentiation among invasive Ponto-Caspian Chelicorophium species (Crustacea, Amphipoda, Corophiidae) by food particle size. Aquat Ecol 52:179-190. https://doi. org/10.1007/s10452-018-9653-8

Borza P, Huber T, Leitner P, Remund N, Graf W (2018b) Correction to: Niche differentiation among invasive PontoCaspian Chelicorophium species (Crustacea, Amphipoda, Corophiidae) by food particle size. Aquat Ecol 52:191-192. https://doi.org/10.1007/s10452-018-9659-2

Bousfield EL, Hoover PW (1997) The amphipod superfamily Corophioidea on the Pacific coast of North America: 5. Family Corophiidae: Corophiinae, new subfamily: systematics and distributional ecology. Amphipacifica 2:67-139
Brönmark C, Malmqvist B (1982) Resource partitioning between unionid mussels in a Swedish lake outlet. Ecography 5:389-395. https://doi.org/10.1111/j.1600-0587. 1982.tb01053.x

Buckley P, Dussart G, Trigwell JA (2004) Invasion and expansion of Corophiidae (Amphipoda) in the Stour estuary (Kent, UK). Crustaceana. https://doi.org/10.1163/ 1568540041643319

Chase JM, Leibold MA (2003) Ecological niches: linking classical and contemporary approaches. University of Chicago Press, Chicago

Ebenman B (1988) Dynamics of age- and size-structured populations: intraspecific competition. In: Ebenman B, Persson L (eds) Size-structured populations: ecology and evolution. Springer, Berlin, pp 127-138

Gerdol V, Hughes RG (1994) Effect of Corophium volutator on the abundance of benthic diatoms, bacteria and sediment stability in two estuaries in southeastern England. Mar Ecol Prog Ser 114:109-115. https://doi.org/10.3354/ meps114109

Grigorovich IA, Angradi TR, Emery EB, Wooten MS (2008) Invasion of the Upper Mississippi River system by saltwater amphipods. Fundam Appl Limnol 173:67-77. https://doi.org/10.1127/1863-9135/2008/0173-0067

Lampert W (1994) Phenotypic plasticity of the filter screens in Daphnia: adaptation to a low-food environment. Limnol Oceanogr 39:997-1006. https://doi.org/10.4319/lo.1994. 39.5.0997

MacDonald EC, Frost EH, MacNeil SM, Hamilton DJ, Barbeau MA (2014) Behavioral response of Corophium volutator to shorebird predation in the Upper Bay of Fundy, Canada. PLoS ONE 9:e110633. https://doi.org/10.1371/journal. pone. 0110633

McCurdy DG, Forbes MR, Logan SP, Lancaster D, Mautner SI (2005) Foraging and impacts by benthic fish on the intertidal amphipod Corophium volutator. J Crustac Biol 25:558-564. https://doi.org/10.1651/C-2539.1

Meßner U, Zettler ML (2018) The conquest (and avoidance?) of the brackish environment by Ponto-Caspian amphipods: a case study of the German Baltic Sea. BioInvasions Rec 7:269-278. https://doi.org/10.3391/bir.2018.7.3.07

Møller LF, Riisgård HU (2006) Filter feeding in the burrowing amphipod Corophium volutator. Mar Ecol Prog Ser 322:213-224. https://doi.org/10.3354/meps322213

Nielsen MV, Kofoed LH (1982) Selective feeding and epipsammic browsing by the deposit-feeding amphipod Corophium volutator. Mar Ecol Prog Ser 10:81-88. https://doi. org/10.3354/meps010081

Noordhuis R, van Schie J, Jaarsma N (2009) Colonization patterns and impacts of the invasive amphipods Chelicorophium curvispinum and Dikerogammarus villosus in the IJsselmeer area, The Netherlands. Biol Invasions 11:2067-2084. https://doi.org/10.1007/s10530-009-94873

Pásztor L, Botta-Dukát Z, Magyar G, Czárán T, Meszéna G (2016) Theory-based ecology: a Darwinian approach. Oxford University Press, Oxford

Pinheiro J, Bates D, DebRoy S, Sarkar D, R Core Team (2020) nlme: linear and nonlinear mixed effects models. R package version 3.1-144, http://CRAN.R-project.org/package= nlme 
Queiroga H (1990) Corophium multisetosum (Amphipoda: Corophiidae) in Canal de Mira, Portugal: some factors that affect its distribution. Mar Biol 104:397-402. https://doi. org/10.1007/BF01314342

R Core Team (2020) R: a language and environment for statistical computing. R Foundation for Statistical Computing, Vienna, Austria. http://www.R-project.org/

Riisgård HU, Larsen PS (2010) Particle capture mechanisms in suspension-feeding invertebrates. Mar Ecol Prog Ser 418:255-293. https://doi.org/10.3354/meps08755

Riisgård HU, Schotge P (2007) Surface deposit feeding versus filter feeding in the amphipod Corophium volutator. Mar Biol Res 3:421-427. https://doi.org/10.1080/ 17451000701696302

Rohlf FJ (2015) tpsDig, Digitize Landmarks and Outlines, version 2.22. Department of Ecology and Evolution, State University of New York, Stony Brook

Shimeta J, Jumars PA (1991) Physical mechanisms and rates of particle capture by suspension-feeders. Oceanogr Mar Biol Annu Rev 29:191-257
Snoeijs-Leijonmalm P, Schubert H, Radziejewska T (eds) (2017) Biological oceanography of the Baltic Sea. Springer Netherlands, Dordrecht

Svensson JR, Marshall DJ (2015) Limiting resources in sessile systems: food enhances diversity and growth of suspension feeders despite available space. Ecology 96:819-827. https://doi.org/10.1890/14-0665.1

Van den Brink FWB, Van der Velde G, Bij de Vaate A (1993) Ecological aspects, explosive range extension and impact of a mass invader, Corophium curvispinum Sars, 1895 (Crustacea: Amphipoda), in the Lower Rhine (The Netherlands). Oecologia 93:224-232. https://doi.org/10. 1007/BF00317675

Zettler ML, Zettler A (2017) Marine and freshwater Amphipoda from the Baltic Sea and adjacent territories. ConchBooks, Harxheim

Publisher's Note Springer Nature remains neutral with regard to jurisdictional claims in published maps and institutional affiliations. 